\title{
ENSINO RELIGIOSO EM PORTO ALEGRE: MODELOS GERAIS E PRÁTICAS ESPECÍFICAS
}

\author{
Giovani Zanirati ${ }^{\mathrm{i}}$
}

\begin{abstract}
Resumo: O presente trabalho é fruto de uma pesquisa que começou em 2014 com o objetivo de observar o material aplicado nas aulas de Ensino Religioso em Porto Alegre. O histórico da disciplina em escolas públicas é marcado por forte presença do cristianismo em seu conteúdo, material escolar, formação dos professores e práticas do dia-a-dia como, por exemplo, orações. Ou seja, além de garantir espaço para uma religião específica se manifestar, a disciplina desconsiderou a pluralidade religiosa existente na sociedade brasileira ao excluir as outras práticas de crenças. Embora seja o comum o privilégio ao cristianismo nas aulas de Ensino Religioso, a pesquisa que efetivei revela um cenário mais complexo.
\end{abstract}

Palavras-chave: Ensino religioso, Cristianismo, Direitos Humanos, Etnografia

\section{RELIGIOUS EDUCATION IN PORTO ALEGRE: General models and specific practices}

\begin{abstract}
The present work is the result of a research that began in 2014 with the objective of observing the material applied in religious education classes in Porto Alegre. The history of the discipline in public schools is marked by a strong presence of Christianity in its content, as weel as in school material, teacher training and day-to-day practices such as prayers. That is, in addition to guaranteeing space for a specific religion to manifest itself, the discipline disregarded the religious plurality existing in Brazilian society by excluding other belief practices. Although the privilege of Christianity is common in religious teaching classes, this research reveals a more complex scenario.
\end{abstract}

Key-words: Religious education, Christianity, Human rights, Ethnography

\section{Introdução}

Não é de hoje que a legitimidade do Ensino Religioso em escolas públicas é marcada por debates entre diversos atores sociais. Os contrários e os favoráveis a presença da disciplina, ao longo do período republicano, apresentam inúmeros argumentos com base na laicidade do Estado brasileiro. Isso acontece porque a ideia de um Estado laico, que determina a separação entre Estado-religião, leva a diferentes interpretações.

Dessa forma, é importante ressaltar a complexidade do conceito. A laicidade é um fenômeno político e não um problema religioso, ou seja, ela deriva do Estado, e não da religião (RANQUETAT JR, 
2008). Um dos pontos de referência é à separação entre Estado e Igreja, conforme citado na Constituição Federal de 1988 no Art. 19, I (BRASIL,1988).

Art.19. É vedada à União, aos Estados, ao Distrito Federal e aos Municípios: estabelecer cultos religiosos ou igrejas, subvencioná-los, embaraçar-lhes o funcionamento ou manter com eles ou seus representantes de relações de dependência ou aliança, ressalvada, na forma da lei, a colaboração de interesse público.

A separação não está necessariamente conectada à laicidade, pois ao adotar o rompimento com a religião, um país pode, simultaneamente, manter relações de privilégios a determinada crença; em contrapartida, um país com uma religião oficial pode ser tolerante e garantir em dispositivos jurídicos a liberdade de manifestação a todas as formas de crenças. De acordo com Oro (2011) o conceito não pode ser abordado de forma universal porque depende do histórico cultural e social de cada país. O autor apresenta três formas de enxergar a laicidade em países da União Europeia e da América Latina: países que mantêm uma separação entre Estado-religião; países que adotam regimes de separação entre religião e Estado com dispositivos particulares em relação a algumas igrejas e religiões; e, por fim, países que adotam o regime de igreja de Estado. Zylberstajn (2012) reforça que o significado de Estado laico está além da definição básica de separação entre Estado e Igreja e os desdobramentos do conceito devem ser explorados dentro do âmbito das práticas de cada país.

A laicidade no Brasil apresenta um campo onde o Estado é neutro, evitando conceder privilégios a qualquer religião; ao mesmo tempo, deve estar presente para evitar práticas de intolerância religiosa e garantir a liberdade de manifestação.

A noção de laicidade, de modo sucinto, recobre especialmente à regulação política, jurídica e institucional das relações entre religião e política, Igreja e Estado em contextos pluralistas. Referese, histórica e normativamente, à emancipação do Estado e do ensino público dos poderes eclesiásticos e de toda referência e legitimação religiosa, à neutralidade confessional das instituições políticas e estatais, à autonomia dos poderes político e religioso, à neutralidade do Estado em matéria religiosa (ou a concessão de tratamento estatal isonômico às diferentes agremiações religiosas), à tolerância religiosa e às liberdades de consciência, de religião (inclusive a de escolher não ter religião) e de culto (MARIANO, 2011, p. 244).

A disciplina Ensino Religioso, um dos principais objetos de discussão, após a $1^{\text {a }}$ Constituição da República (1891), foi excluída da grade escolar. Contudo, a força católica no país foi suficiente para recuperar privilégios e aderir, mais uma vez, à escola pública como campo de atuação, em 1934, de acordo com o Art. 153 (BRASIL, 1934). O artigo determina que a disciplina seja "ministrada de acordo com os princípios da confissão religiosa do aluno manifestada pelos pais ou responsáveis" (BRASIL, 1934). Por consequência, nas primeiras décadas (1930-60), existia uma presença hegemônica do catolicismo, pois a 
religião era a única com capacidade para se organizar e oferecer profissionais capacitados para exercerem a função. Conforme Santos (2013) destaca, o Ensino Religioso tinha uma perspectiva catequética.

\begin{abstract}
Por muitas razões, a Igreja Católica teve um papel crucial na definição do novo regime de relações entre Estado e religião no Brasil republicano. Ressalta-se bastante o fato de que a Igreja Católica foi contrária à sua separação com o Estado. E é fácil de mostrar como seus líderes e representantes se empenharam na defesa do regime contrário ou de algum tipo de reconhecimento, por parte do Estado, da preeminência do catolicismo na constituição da nacionalidade (GIUMBELLI, 2008, p. $82)$.
\end{abstract}

A partir da década de 1970, a disciplina passou por algumas transformações para, deste modo, se adequar a pluralidade religiosa existente no Brasil. Se na primeira ocasião, os alunos e os professores eram separados de acordo com a crença (modelo confessional); o novo modelo tentaria apresentar um conteúdo único, que conseguisse atender a todos os estudantes, sem precisar separá-los (modelo não confessional).

Em suma, a minha intenção ao realizar a pesquisa, é compreender o conteúdo aplicado nas aulas de religião na cidade de Porto Alegre, Rio Grande do Sul. O trabalho é proposto da seguinte maneira: na primeira parte, faço um levantamento sobre os modelos propostos pelo Estado, onde se nota a presença, em vários aspectos, do cristianismo como ensino padrão, estabelecendo limites às outras crenças ${ }^{\mathrm{ii}}$. Em seguida, o destaque para o modelo alternativo de Ensino Religioso em uma escola pública de Porto Alegre - um conteúdo, que ao contrariar o estigma que a disciplina carrega, não utiliza preceitos religiosos em sala de aula, e sim um material que discute sobre os problemas sociais, como machismo, homofobia e racismo.

\title{
Modelos gerais
}

Após retornar, oficialmente à grade escolar em 1934, o Ensino Religioso sofreu transformações para, deste modo, se adequar à pluralidade religiosa presente na sociedade brasileira ${ }^{\text {iii }}$. No decurso de 84 anos, foram apresentados diversos modelos. Com objetivo de simplificar, irei desenvolver como objeto de estudo, o confessional e o não confessional.

O confessional se perpetuou durante as décadas de 30 até 60 , mas ainda se encontra presente em alguns estados brasileiros como, por exemplo, no Rio de Janeiro ${ }^{\text {iv }}$. O não confessional começou a ser elaborado a partir da década de 70 e denota maior fôlego, sendo amparado pela Lei de Diretrizes e Bases da Educação Nacional - LDB- Lei 9.394/96 (BRASIL, 1996), o Fórum Nacional Permanente do Ensino Religioso (FONAPER) ${ }^{\mathrm{v}}$ e órgãos destinados à disciplina como o Conselho de Ensino Religioso do Estado do Rio Grande do Sul (CONER-RS) que contribui para regulamentação da disciplina.

O modelo confessional solicita o ensino exclusivo de acordo com a crença do aluno ou dos pais/responsáveis; as aulas ficariam sob a responsabilidade de professores próximos à religião. O não 
confessional possui como característica o diálogo entre as diversas religiões, em forma de conteúdo singular, sem separar o alunado. Segundo Giumbelli (2011) o modelo procura contemplar a diversidade religiosa por meio de um conteúdo comum, que serviria como referência para o trabalho dos professores. Porém, diferentemente do confessional, sua definição abre a possibilidade de ramificações.

Na verdade, o que seria o modelo não confessional não designa uma configuração tão precisa quanto à primeira, daí a multiplicação dos termos para denominá-lo, quando essa denominação existe: interconfessional, supraconfessional, não confessional, ecumênico, inter-religioso (GIUMBELLI, 2011, p. 262).

Conforme exposto no texto, a presente metodologia é aparada pelo FONAPER e pelas leis de diretrizes. Atual versão da LDB-EN (BRASIL, 1996), sendo o texto original modificadovi, determina.

Art. 33. O ensino religioso, de matrícula facultativa, é parte integrante da formação básica do cidadão e constitui disciplina dos horários normais das escolas públicas de ensino fundamental, assegurando o respeito à diversidade cultural religiosa do Brasil, vedadas quaisquer formas de proselitismo.

$\S 1^{\circ}$ Os sistemas de ensino regulamentarão os procedimentos para a definição dos conteúdos do ensino religioso e estabelecerão para a habilitação e admissão dos professores.

$\S 2^{\circ}$ Os sistemas de ensino ouvirão entidade civil, constituída pelas diferentes denominações religiosas, para a definição dos conteúdos do ensino religioso.

De acordo com a LDB, a disciplina de religião deve ser utilizada como espaço onde as diferenças possam coexistir e serem respeitadas, porém apresenta irresoluções. Assim como a Constituição de 1988 no seu art. 210, $\S 1^{\circ}$ (BRASIL, 1988): “o ensino religioso, de matrícula facultativa, constituirá disciplina dos horários normais das escolas públicas de ensino fundamental", a LDB não define a forma de conteúdo a ser trabalhado, ficando sob responsabilidade de cada instituição de ensino. Devido à indefinição, o modelo não consegue cumprir a proposta de excluir as práticas doutrinárias e valorizar a diversidade religiosa. "O fato de que as modalidades não confessionais detenham maior disseminação e legitimidade não significa que estejam ao abrigo de problematizações" (GIUMBELLI, 2011, p. 263).

Em ambos os modelos são expostos às mesmas contradições: a construção de um ambiente que permite o proselitismo em sala de aula. Este aspecto cria um cenário possivelmente contrário ao que determina a laicidade do Estado brasileiro, que, segundo Fischmann (2012), lhe permite separar-se e distinguir-se das religiões, oferecendo à esfera pública e à ordem social a possibilidade de convivência da diversidade e da pluralidade humana.

Cabe lembrar dois casos que reforçam a existência de privilégios ao catolicismo frente ao Ensino Religioso. Primeiro, o Acordo promulgado entre Brasil e a Santa Sé de Roma, segundo o decreto n ${ }^{\circ} 7.107$ 
(BRASIL, 2010) que apresenta um estatuto jurídico da Igreja Católica no Brasil. A Lei promulga o Acordo entre o Governo da República Federativa do Brasil e a Santa Sé relativo ao Estatuto Jurídico da Igreja Católica no Brasil, firmado na Cidade do Vaticano, em 13 de novembro de 2008 (BRASIL, 2010). Ao tratar sobre a disciplina, a concordata modifica o texto original da atual LDB ao indicar "o ensino religioso católico e de outras confissões religiosas". O documento assinado retrata privilégios à Igreja Católica, pois o ensino católico não é previsto na Constituição de 1988 e nem na LDB. Segundo, a decisão da maioria dos ministros de negar o pedido de Ação Direta de Inconstitucionalidade (ADI) 4.439 apresentado no Supremo Tribunal Federal (STF)vii. Na ocasião, a Procuradoria Geral da República (PGR) fez um pedido de revisão do modelo confessional, pois violaria a Constituição e o princípio de laicidadeviii. Entretanto, a maioria (6x5) decidiu pela improcedência da ação e que o Ensino Religioso poderia identificar o modelo confessional. O argumento utilizado é que as normas não ofendem a Constituição, pois garantem a liberdade de expressão e, também, pela facultatividade da disciplinaix. O FONAPER, em nota pública, demonstrou insatisfação diante da decisão do Supremo Tribunal Federal.

Há mais de duas décadas o Fonaper vem trabalhando para propor e consolidar o ensino religioso como uma área de conhecimento responsável por tornar o conhecimento religioso um objeto a ser estudado em perspectiva histórica, social, científica e cultural, uma vez que estes saberes são resultantes das formulações de diferentes tradições e movimentos religiosos que ao longo da história da humanidade contribuíram para a estruturação da vida em sociedade (FONAPER, 2017).

Os defensores do Ensino Religioso nas escolas públicas reiteram a religião como uma ferramenta para contribuir com a formação moral dos estudantes. Lembrando que, no início do Século XX, grupos católicos acreditavam que a disciplina exercia importante função na formação dos jovens. De acordo com Ranquetat Jr (2007) os favoráveis à presença do Ensino Religioso (bispos e a intelectualidade católica conservadora da $1^{\circ}$ República) destacavam que tentar impedir a presença da disciplina marcaria uma forma de intolerância com a religião da maioria da população e o direito dos estudantes de receberem conteúdos ligados à sua crença. Uma escola neutra seria ateísta e irreligiosa. Para os críticos (liberais, maçons, positivistas, socialistas e alguns protestantes) do proselitismo e defensores de uma escola laica, a existência da disciplina significava a presença do elemento eclesial na escola, servindo aos interesses da Igreja Católica (RANQUETAT JR, 2007, p.166).

Ao compartilhar da perspectiva de uma escola laica, Roseli Fischmann, Doutora em Filosofia e História da Educação, é crítica à presença do Ensino Religioso, independentemente do modelo proposto, pois considera um risco de violação frente à presença da mesma divindade que, imposta mesmo inconscientemente ao outro, produz uma visão a ser aceita como verdadeira (FISCHMANN, 2015). Fischmann questiona a ideia de que o Ensino Religioso é capacitado como meio de combate a violência e 
os diversos problemas sociais. Este trabalho, a seu ver, deveria ser realizado a partir de um conteúdo voltado aos direitos humanos, considerando o respeito às minorias (FISCHMANN, 2015).

A escola, na perspectiva laica, deve se manter neutra em relação às religiões, mas presente em trabalhar questões sobre desigualdade e respeito às especificidades de cada grupo social. O espaço escolar, dessa maneira, deveria exercer a função de estimular a consciência e o conhecimento para que os estudantes possam construir um ambiente de sociabilidade justo e favorável a todos, independentemente de suas características culturais e sociais. É necessário analisar a experiência pessoal e a dos outros dentro do contexto da sociedade para, se possível, se afastar da "bolha social" e conhecer os problemas estruturais.

Por fim, como será utilizar este tipo de metodologia, nas aulas de religião, em um período marcado de discussões sobre retrocesso e perseguição aos educadores? Não custa lembrar que Jair Bolsonaro do Partido Social Liberal (PSL), eleito presidente da República, em outubro de 2018x, se mostra crítico à ideologia freireana e de gênero nas escolas e, durante boa parte da campanha, ressaltou a necessidade de combatê-lasxi. Segundo ele, os professores não poderiam tratar de temas vistos como polêmicos em sala de aula, para evitar uma suposta doutrinação.

Por sua vez, nesse contexto, se destaca a presença do professor José, interlocutor da minha pesquisa de campo, que trabalha assuntos alternativos durante as aulas de Ensino Religioso. Sua metodologia tornase um desafio não só para a disciplina; mas, também, para o restante do ambiente escolar.

\section{O Ensino Religioso na escola: Práticas específicas}

Durante os meses de julho até novembro de 2018, realizei uma pesquisa de campo em uma escola pública de Porto Alegre. O nome da escola, conforme prometido aos professores e a coordenadora Reginaxii, será mantido em sigilo; os nomes de todos os interlocutores (coordenadora, professores, alunos) são fictícios. A escola de ensino médio, que se encontra em uma zona central da cidade, atende 600 estudantes. Segundo Claudia, professora de Geografia, e a primeira a assumir a disciplina, o Ensino Religioso é novo na escola, porque, anteriormente, era oferecida uma disciplina voltada para os direitos humanos.

$\mathrm{Na}$ época citada pela professora, os alunos realizaram diversos trabalhos (história em quadrinhos, exposição de máscaras, curta-metragem) que foram apresentados em eventos escolares. Contudo, após a eleição de José Ivo Sartori (MDB) para Governador do Estado do Rio Grande do Sul em 2014, o cenário foi modificado. No governo Sartori (2015-2018), a disciplina foi substituída pelo Ensino Religioso, mesmo frente ao questionamento da escola. Ela reforça que um "homem de influência da Igreja Católica" presente na Secretaria de Educação do Rio Grande do Sul seria o responsável por essa imposição. A disciplina, 
diferentemente da orientação da LDB-EN, não é facultativa, ou seja, os alunos são obrigados a frequentar e correm o risco de serem reprovados.

De acordo com a LDB, o Ensino Religioso faz parte do horário normal e as escolas devem, obrigatoriamente, oferecer outra atividade para os estudantes que decidem não acompanhar as atividades de religião. Porém, devido à fraca infraestrutura, muitas escolas não conseguem oferecer atividades alternativas e, deste modo, todos os alunos frequentam a disciplina.

Algumas escolas costumam não informar aos alunos sobre a facultatividade da disciplina, usando às vezes métodos questionáveis para forçar os alunos a cursarem-na e, assim, desincumbirem-se de oferecer atividade alternativa (SANTOS, 2013, p. 99).

A professora Claudia respondeu que o material organizado deve ser assimilável para impedir a reprovação dos alunos. "Se o aluno for reprovado em duas matérias - mesmo que uma seja de religião ele terá que repetir o ano, isso é um absurdo. Se os pais tiverem conhecimento sobre a constituição, podem denunciar a escola ao Ministério Público" disse a professora.

A professora não desejava exercer a função, pois acredita que os responsáveis pelo Ensino Religioso acabam, mesmo involuntariamente, impondo a própria visão aos alunos. Ela, por sua vez, evitou inserir práticas confessionais em sala de aula. "Não acho correto aplicar o ensino de uma religião em escola pública, se fosse uma escola particular, o processo poderia ser diferente" disse a professora. Mas, devido ao interesse de alguns alunos, o assunto eventualmente aparecia em discussões. "Alguns alunos colocaram em debate até o satanismo; não tinha conhecimento que se tratava de uma religião, mas fui pesquisar". Os alunos, segundo a professora, assimilaram bem os conteúdos e ela não presenciou nenhuma forma de intolerância em sala de aula. Ainda, acrescentou que os adeptos do protestantismo são os que têm mais coragem para se manifestar.

Após este período, o professor José assumiu o lugar de Claudia. Ele é formado em História, e tem experiência como de Ensino Religioso desde 2014xiii. Em uma escola de ensino fundamental, José ministrou as aulas da disciplina e, desde então, começou a aplicar um modelo alternativo, que se afasta de materiais religiosos.

Eu tive a oportunidade, durante uma pesquisa sobre o Ensino Religioso, de acompanhar as aulas de José. Devido à metodologia adotada pelo professor, considerei importante dar sequência a pesquisa. A diferença está relacionada às escolas: A primeira escola, de ensino fundamental, está localizada em um bairro rural da cidade de Porto Alegre e atende os estudantes do local e de bairros próximos; a segunda escola, de ensino médio, está localizada em uma zona central de Porto Alegre e recebe alunos de diversas regiões da cidade. Na presente escola, ele se interessou pelo programa da disciplina anterior (sobre direitos humanos) e tenta seguir o material. A exclusão da religião, segundo o professor, é o caminho adequado, 
assim mantém a neutralidadexiv. O conteúdo apresentado, em alguns casos da escolha dos estudantes, é relacionado a diversos problemas debatidos pela sociedade.

Em conversa, durante as aulas, ele disse que utilizou, em um primeiro momento, o Dia Internacional da Mulher (08 de Março) para debater com os alunos sobre "violência contra as mulheres". Segundo o professor, o tema foi bem aceito e algumas questões foram colocadas em pauta, como o assédio sexual e a forma como a sociedade enfrenta o problema. Porém, no segundo tema, a recepção encontrou resistência. José propôs um trabalho sobre "representatividade LGBT em filmes, séries e livros", e alguns estudantes demonstraram desconforto para discutir o tema e, por fim, não entregaram a tarefa.

\section{O debate em sala de aula}

Minha presença em sala de aula ocorreu em duas turmas do $1^{\circ}$ Ano do ensino médio; sendo assim, os alunos citados serão diferenciados de acordo com a turma: $1^{\circ}$ turma do ensino médio (EM1) e $2^{\circ}$ turma do ensino médio (EM2). No período em que estive no campo, o professor tratou de quatro temas: 1) Porte/posse de armas; 2) A influência de youtubers na formação dos jovens; 3) Desigualdade social; e 4) Dia da Consciência Negra.

Sobre o tema "porte/posse" de armas, José pediu que os alunos pesquisassem sobre leis que permitem o acesso a arma de fogo, iniciando um debate sobre o papel do Estado sobre o tema e o medo do aumento da violência. Os alunos falaram que a população deseja o direito de comprar uma arma devido ao medo da violência. Contudo, segundo os estudantes, bandido é preso e morto o tempo inteiro e, mesmo assim, ela não diminui. Ou seja: armar a população não seria a solução. A resposta passaria por investimentos na área da educação, emprego e políticas públicas para a redução da desigualdade social. Em sequência, os estudantes fizeram críticas aos políticos - constantemente apontados como os verdadeiros bandidos. Franciely (EM1) acredita que existem políticos envolvidos com tráficos de drogas, mas quem acaba criminalizado é o jovem de periferia. Os políticos, segundo ela, tentam mascarar a realidade ao construir determinados sujeitos como inimigos, enquanto os verdadeiros criminosos estão soltos. Pablo (EM2) lembra que a população "deseja escutar o que quer e não o que precisa". Ele acredita que as pessoas não estão preparadas para terem uma arma de fogo; elas, para dizer a verdade, estariam sendo enganadas por políticos oportunistas que desejam se aproveitar do medo da população para ganhar representatividade. Porém, é o Estado que deve garantir a segurança das pessoas; o Estado não pode fugir da responsabilidade e colocar armas nas mãos das pessoas e dizer: "vai, se defenda". Em resumo, os estudantes alertaram que o Brasil atravessa um período conturbado, onde seria perigoso facilitar o acesso às armas. A violência, dessa forma, só iria aumentar. 
No segundo tema proposto pelo professor, os alunos debateram sobre a "influência de youtubers" como formadores de opinião. É inegável a presença dos influenciadores digitais, conhecidos como formadores de conteúdo, na vida dos adeptos as redes sociais. Eles atingem milhões de seguidores e visualizações, criando uma base fiel de fãs, tornando-se novas celebridades, empresários do ramo e garantindo contratos com multinacionais. A função dos youtubers acaba sendo mais complexa do que se imagina; eles, por exemplo, podem ser vistos como sujeitos sociais que se transformaram em agentes de opinião, com a capacidade de conhecerem as preferências dos grupos sociais e suas trajetórias.

Porém, este tipo de relação pode se tornar polêmica. O professor citou dois youtubers que foram alvo de debates devido a piadas controversas. No primeiro caso, Júlio Cocielo com mais de 18 milhões de seguidores no YouTube, fez um comentário de cunho racista, durante a Copa do Mundo de 2018, ao dizer que o jogador da França Kyllian Mbappé, atleta negro, "faria um arrastão top na praia" devido à velocidade xv. Após a pressão dos críticos e a perda de publicidades, Cocielo gravou um vídeo e pediu desculpas pelo ocorridoxvi. Em outro caso de grande repercussão, Everson Zoio, com mais de 11 milhões de seguidores no YouTube, relatou aos amigos detalhes de como abusou da ex-namorada. O caso foi investigado pela delegacia de Belo Horizonte, mas Zoio disse que o vídeo era uma brincadeiraxvii.

Os estudantes foram incisivos ao afirmar que o racismo e o machismo não são piadas. Eles defenderam o "lugar de fala" de cada grupo social, como algumas estudantes que criticaram a visão sobre a mulher na sociedade. Gabriela (EM1) criticou a visão sobre as mulheres na sociedade. "As mulheres são criadas para serem mães e donas de casa; elas ganham de presentes uma boneca e panelas, enquanto os meninos têm maior liberdade". Ela questiona os aspectos inatos e psicológicos como preponderantes na construção do papel feminino na sociedade. Eduarda (EM1) diz que o sistema patriarcal tem como função submeter às mulheres a certos padrões, normalmente inferior aos homens.

Ao escutar as jovens, coloco em diálogo os pensamentos da filósofa Donna Haraway sobre a posição das mulheres e as questões naturais e culturais. Haraway (2004) sugere que as questões sobre identidade de gênero (questões sociais e culturais) devem ser distintas do sexo (biológico) e que as feministas para lutarem contra a opressão na sociedade tentaram argumentar contra o "determinismo biológico" e a favor do “construcionismo social”. Esta distinção era muito útil no combate aos determinismos biológico pervasivos e constantemente utilizados contra feministas em lutas políticas urgentes a respeito das "diferenças sexuais" nas escolas, nas editoras, nas clínicas e assim por diante (HARAWAY, 2004, p. 218).

Durante o debate, Jonas (EM2) disse que a piada de Cocielo foi mal interpretada e, dessa maneira, não foi uma ação racista. Tamy (EM2) disse que ele associou a isso a cor do jogador e, caso Mbappé fosse branco, a piada não aconteceria. Ela elevou o tom da voz, durante a discussão, e acrescentou a existência de um racismo explícito no Brasil, as piadas seriam uma forma de mascarar a visão preconceituosa. José que acompanhava o debate dos alunos se manifestou sobre o "lugar de fala" e como ele pode ser aplicado 
no debate. O professor alertou que tanto ele quanto Jonas não poderiam afirmar que a piada não é racista, pois eles não são negros e, assim, não teriam condições de entender o que seria ofensa ou uma brincadeira. Através de um exemplo, ele acrescenta em sua posição: "Eu sou gay. Então, caso uma pessoa me chame de bicha, eu ficaria ofendido. Não vai ser um heterossexual que vai dizer como devo sentir, entende? Afinal, ele não tem como entender. Apenas quem sofre o preconceito e a violência conseguem entender o quanto uma palavra, uma piada podem ser ofensivos".

\section{Materiais utilizados}

É possível, desta forma, compreender que metodologia adotada pelo professor se diferencia em relação aos modelos históricos do Ensino Religioso. Modelos que, de acordo com diversas pesquisas realizadas, exemplificam um cenário favorável à presença da religião cristã. Segundo Valério (2008) os professores das escolas públicas de Pernambuco se declaram como católicos ou protestantes e desconhecem as outras religiões; e que a Bíblia e textos cristãos tornam-se materiais de ensino. Santos (2016) destaca que nas escolas públicas de São Paulo e Campinas os materiais destinados ao Ensino Religioso prezam pela prática cristã em seus conteúdos e alguns livros abordam o tema da cultura religiosa afro-brasileira superficialmente. Segundo Santos (2013), os cursos de extensão ou especialização sobre o Ensino Religioso também são oferecidos quase que exclusivamente por instituições de ensino superior alinhada ao pertencimento religioso cristão.

O professor José, conforme exposto ao longo do texto, busca autonomia para exercer a função e escolhe o próprio materialxviii. Em algumas oportunidades, ele utiliza a sala de informática para os estudantes realizarem as pesquisas. Os alunos utilizaram a ferramenta para conhecerem sobre o porte e posse de armas, a primeira atividade realizada durante o trabalho de campo; e, também, para acompanharem a história em quadrinho on-line "Quem Matou Caixeta?" escrita por Rainer Petterxix, durante a atividade sobre a influência de youtubers. Na história, o personagem Caixeta (o personagem tem uma caixa de papelão que cobre a cabeça) é um youtuber que utilizava seu canal para proferir diversas manifestações de ódio e preconceito contra as mulheres, as lésbicas, os gays e os negrosxx.

Pablo (EM2) fez referência ao personagem ao dizer que o personagem vivia dentro de uma bolha social (a caixa significava a bolha). O personagem, segundo o estudante, não conseguia compreender o mal que estava fazendo e ficava triste com as críticas, mas segundo o irmão de Caixeta, ele deveria continuar com o trabalho e ignorar "os comentários esquerdistas e de todos esses otários que bancavam de politicamente corretos". Pablo reforça que as pessoas acabam evitando escutar opiniões contrárias por estarem dentro da "bolha" criando um conflito que poderia ser evitado. 
Além do recurso online, José utiliza a sala de vídeo. Em uma das atividades, os alunos assistiram ao filme “Que Horas Ela Volta?”. O filme conta a história de Val, nascida em Pernambuco, que, após se mudar para a cidade de São Paulo, começou a trabalhar como doméstica para uma família de classe média. Com o passar do tempo, ela se tornou residente da casa e enviava dinheiro para a filha Jéssica que morava no interior de Pernambuco. Anos depois, Jéssica decidiu ir para São Paulo, para prestar a prova do vestibular. Até o dia da prova, ela ficou na casa dos patrões de Val. O resultado foi conturbado, pois Jéssica quebrou alguns tabus estabelecidos para os empregados da residência, como dormir no quarto de hóspedes, jantar na mesa da sala, tomar banho de piscina, etc. Val, que era considerada "como da família" pelos donos da casa, sabia, involuntariamente, da existência de uma barreira que a impedia de fazer coisas semelhantes. Contudo, Jéssica conseguiu apresentar à mãe uma realidade diferente do que imaginava. Após o filme, o professor explicou que a intenção era expor os problemas da desigualdade social e como ela cria barreiras ao separar as pessoas de acordo com a realidade financeira.

Por fim, na última atividade que consegui presenciar, o professor trabalhou o Dia da Consciência Negra. É de conhecimento a dificuldade em tratar o tema em sala de aulaxxi. Este problema vai contra avanços sociais na área da educação, como a Lei $n^{\circ}$ 10. 639 (BRASIL, 2003) que passa a incluir oficialmente na rede de ensino a obrigatoriedade da temática "História e Cultura Afro-Brasileira". Porém, estes instrumentos não chegam devidamente às salas de aula, "lembrando que as questões que se referem às religiões afro-brasileiras, por exemplo, também se mostram relevantes para um entendimento do que é o Brasil" (OLIVEIRA, 2014, p. 177). Assim, explica-se, também, a ausência de estudos voltados para as religiões afro-brasileiras nas escolas.

Segundo Cavaliere (2007), o fato de os adeptos dessas religiões nas escolas não se manifestarem sobre o assunto é um problema preocupante a ser compreendido e considerado como um sinal do preconceito e do possível crescimento da intolerância religiosa. De acordo com Oro (1997), esse tipo de perseguição, atualmente associada às religiões neopentecostais, tem como motivos a demonização (discursos acusatórios marcados por agressões e preconceito) e a lógica mercadológica, ou seja, disputa por novos fiéis, normalmente em zonas urbanas menos favorecidas.

Durante a atividade, o professor pediu para os alunos formassem grupos para se apresentarem na "Feira das nações africanas". A atividade envolveu todos os alunos do primeiro ano e contou com a participação de outros professores. Cada grupo, após um sorteio, ficou responsável por um país do continente africano. Eles deveriam recolher todas as informações possíveis sobre os aspectos culturais, religiosos e políticos do país para a apresentação. Ele, após explicar o formato do trabalho, disse que os alunos estavam proibidos de realizarem black face, uma prática onde artistas brancos se pintam de pretos para interpretarem personagens negros. Nesta prática, em muitas oportunidades, o personagem é moldado de forma que contribui com os estereótipos que servem para ridicularizar os negros. 
Segundo o professor, as dificuldades enfrentadas pelos negros no Brasil devido à escravidão - na sua visão, apresentada como um fato curioso da história - e as mudanças pouco efetivas, após o período, que inseriram a população negra em um contexto subalterno, foi o principal motivo para trabalhar o tema. Ao escutar a manifestação do professor, lembrei-me do antropólogo Darcy Ribeiro (1995), que criticou a falta de assistência à população negra após a escravidão. Os negros estariam inseridos em um ambiente violento de repressão, pois a elite econômica era composta por filhos e netos dos senhores de escravos que mantinham o mesmo desprezo pelos negros. Dessa forma, não ocorreu acesso ao trabalho e à educação. O autor explica que este processo construiu um estereótipo e forte influência ao preconceito, onde a população branca opta por converter o negro em responsável pelas adversidades enfrentadas ao invés de reconhecer o histórico de desigualdade.

Todos eles são tidos consensualmente como culpados de suas próprias desgraças, explicadas como características da raça e não como resultado da escravidão e da opressão. Essa visão deformada é assimilada também pelos mulatos e até pelos negros que conseguem ascender socialmente, os quais se somam ao contingente branco para discriminar o negro-massa (RIBEIRO, 1995, p. 222).

A apresentação do trabalho ocorreu no dia 10/11, em um sábado, durante o período da manhã. Ao todo, 171 alunos (divididos em 29 grupos, isto é, 29 países representados) colaboraram com a atividade. Ao longo da manhã, os grupos expuseram desenhos das bandeiras dos países - em cartolinas, folhas de papel e tecido - e relataram sobre o histórico político e cultural dos países. Os estudantes levaram para a apresentação dos trabalhos: maquetes, desenhos, mapas, imagens dos pontos turísticos e personalidades, músicas tradicionais (os alunos utilizaram a rede YouTube como forma de encontrar as músicas) e máscaras. Alguns estudantes estavam com os rostos pintados com simples riscos nos dois lados do rosto ou com pontilhados coloridos ao redor dos olhos.

\section{Considerações Finais}

Ao iniciar a pesquisa sobre o Ensino Religioso, a intenção era observar a presença, em forma de conteúdo, da religião em sala de aula. O histórico da disciplina em escolas públicas, conforme apresentando no texto, constrói uma relação entre o cristianismo (principalmente o catolicismo) e o espaço público. Ou seja: uma considerável distância entre as normas e as práticas da disciplina. A presença do cristianismo se faz presente de inúmeras maneiras, construindo um ambiente onde a diversidade não é representada, tornando a escola pública um espaço para o proselitismo. Porém, após acompanhar as aulas e os relatos dos professores, foi possível observar um cenário onde a religião perde, consideravelmente, espaço para temas gerais sobre os direitos humanos. O tema, quando esteve presente, ocorreu mais por um aspecto de 
curiosidade dos alunos do que interesse dos professores em debater sobre "história das religiões". Dessa forma, as práticas, devido à ausência de um conteúdo específico, podem variar de acordo com a formação do professor (inclusive religiosa), criando a possibilidade de modelos alternativos.

Por consequência, a etnografia realizada em Porto Alegre, foi uma ferramenta importante para compreender as dinâmicas do Ensino Religioso. A presença em sala de aula foi influenciada pelos poucos materiais acadêmicos similares. De acordo com Santos (2013, p.23) existe a necessidade de entender o ensino religioso em um local essencial, mas que não recebe a devida atenção: a sala de aula. Giumbelli (2011, p.279) também considera importante incluir dados e observação acerca de como o Ensino Religioso tem sido tratado nas escolas, cruzando visões e práticas de professores com a administração da direção institucional. Por fim, ao longo das aulas de Ensino Religioso sem a presença da religião, José levou à sala de aula, através de materiais didáticos (filmes, músicas, vídeos, HQs), a sua perspectiva social e militânciaxxii, com objetivo de conscientizar os alunos sobre a importância do conhecimento, do debate, das diferenças, da inclusão das minorias, etc. Dessa maneira, consegue inserir a escola em uma função que vai além do ensino básico, contribuindo para a socialização e sociabilidade dos estudantes. Acredito que, baseado na manifestação nos debates, os estudantes conseguiram compreender a metodologia do professor.

Os estudantes, por sua vez, mesmo que uma parte tenha permanecido em silêncio, se manifestaram constantemente, defendendo seus pontos de vistas e, também, o direito das minorias. Por exemplo, o professor José, em uma mensagem pelas redes sociais, mencionou que, mesmo diante do retrocesso político que o Brasil está passando, presenciou um momento de satisfação e comoção. Alguns estudantes levaram à escola um cartaz para comemorar o casamento civil de José com seu parceiro. O professor comentou que a ação dos alunos o fez perceber que está no caminho certo; e, por fim, concluiu: "Enquanto alguns alunos denunciam professores por doutrinação, os meus fizeram um cartaz lindo pelo meu casamento. Nós vamos vencer com amor".

\section{Referências Bibliográficas}

BRASIL. Art. 153 da Constituição Federal de 16 de Julho de 1934. Disponível em: < https://www.jusbrasil.com.br/topicos/10616437/artigo-153-da-constituicao-federal-de-16-de-julho-de$\underline{1934}$ >. Acesso em: 31 jul. 2019.

Art. 19, I da Constituição da República Federativa do Brasil de 5 de outubro de 1988. Disponível em: 〈http://www.planalto.gov.br/ccivil_03/Constituicao/Constituicao.htm >. Acesso: 31 jul.2019. 
. Art. $210, \S 1^{\circ}$. Constituição da República Federativa do Brasil de 5 de outubro de 1988. Disponível em: <http://www.planalto.gov.br/ccivil_03/Constituicao/Constituicao.htm> Acesso: 31 jul. 2019.

. Lei de Diretrizes e Bases da Educação Nacional (LDBN) nº 9394/96, de 20 de dezembro de 1996.

Disponível em: <https://www.jusbrasil.com.br/topicos/11690993/artigo-33-da-lei-n-9394-de-20-dedezembro-de-1996 > Acesso em: 31 jul. 2019.

. Lei n. ${ }^{\circ} 10.639$, de 9 de janeiro de 2003. Altera a Lei ${ }^{\circ}$ 9.394, de 20 de dezembro de 1996, que estabelece as diretrizes e bases da educação nacional, para incluir no currículo oficial da Rede de Ensino a obrigatoriedade da temática "História e Cultura Afro-Brasileira", e dá outras províncias. Disponível em: < http://www.planalto.gov.br/ccivil_03/Leis/2003/L10.639.htm>. Acesso: 31 jul.2019.

. Lei $n^{\circ}$ 7. 107, de 11 de fevereiro de 2010. Promulga o Acordo entre o Governo da República Federativa do Brasil e a Santa Sé relativo ao Estatuto Jurídico da Igreja Católica no Brasil, firmado na Cidade do Vaticano, em 13 de novembro de 2008. Disponível em: <http://www.planalto.gov.br/ccivil 03/ Ato2007-2010/2010/Decreto/D7107.htm>. Acesso em: 31 jul. 2019.

CAVAliERE, Ana Maria. O mal-estar do ensino religioso em escolas públicas. Cadernos de Pesquisa, v. 37, n. 131, p 303-332, 2007.

FISCHMANN, Roseli. Estado laico e o direito a ter direitos. São Paulo: Factash, p. 16-24, 2012.

. Escolas públicas e ensino religioso: subsídios para a reflexão sobre o Estado laico, a escola pública e a proteção do direito à liberdade de crença e de culto. 21 out. 2015. Disponível em: $<$ http://egov.ufsc.br/portal/conteudo/escolas-p\%C3\%BAblicas-e-ensino-religioso-subs\%C3\%ADdiospara-reflex\%C3\%A3o-sobre-o-estado-laico-escola>. Acesso em: 16 nov. 2018.

FONAPER Nota Pública contra o ensino religioso confessional na escola pública, 2017. Disponível em: <http://www.fonaper.com.br/noticia.php?id=1997 >. Acesso em: 16 nov.2018.

GIUMBELLI, Emerson. A presença do religioso no espaço público: modalidades no brasil. Religião e Sociedade, Rio de Janeiro, v. 28, n. 2, p. 80-101, 2008.

. Ensino religioso e assistência religiosa no Rio Grande do Sul: quadros exploratórios. Civitas, Porto Alegre, v. 11, n. 2, p. 259-283, 2011.

HARAWAY, Donna “Gênero" para um dicionário marxista: a política sexual de uma palavra. Cadernos pagu (22) 2004: pp.201-246.

MARIANO, Ricardo. Laicidade à brasileira. Civitas, v. 11, n. 2, p. 238-258, 2011.

OLIVEIRA, Amurabi. A vez das religiões afro-brasileiras no ensino religioso? As possibilidades e limites abertos pela lei n. ${ }^{\circ}$ 10.639/03. Revista de Estudos e de Pesquisa da Religião, Juiz de Fora, v. 17, n. 1, p. 171-188, 2014. 
ORO, Ari Pedro. A laicidade no Brasil e no Ocidente. Algumas considerações. Civitas - Revista de Ciências Sociais, v. 11, n 2, p. 221-237, 2011.

Neopentecostais e afro-brasileiros: quem vencerá esta guerra? Debates do Ner, v. 1, n. 1, p. 10-36, 1997.

RANQUETAT JR., Cesar. Laicidade, laicismo e secularização: definindo e esclarecendo conceitos. Revista Sociais e Humanas, v. 21, n. 1, 2008.

Religião em sala de aula: o ensino religioso em escolas públicas brasileiras. CSO online (Revista Eletrônica das Ciências Sociais), ano 1, ed. 1, 2007.

RIBEIRO, Darcy. Classe e Raça. In: O povo brasileiro: a formação e o sentido do Brasil. 2. ed. São Paulo: Companhia das Letras, p. 219-228, 1995.

SANTOS, Milton Silva dos. Religião e demanda: o fenômeno religioso em escolas públicas. Tese - Instituto de Filosofia e Ciências Humanas, Universidade Estadual de Campinas, Campinas, 2016.

SANTOS, Renan Bulsing dos. Religião é igual, religião é diferente: reflexões a partir do ensino religioso em escolas públicas de Porto Alegre. Dissertação (Mestrado em Antropologia Social) - Instituto de Filosofia e Ciências Humanas, Universidade Federal do Rio Grande do Sul, 2013.

VALÉRIO, Denise Bezerra: O ensino religioso na escola: uma questão complexa. Monografia (PósGraduação Lato Sensu Ensino da História) - Programação de Ensino de História, Centro de Ensino Superior de Arco Verde, Universidade de Pernambuco, Arco Verde, 2008.

ZYLBERSZTAJN, Joana. O princípio da laicidade na Constituição de 1988. São Paulo: Faculdade de Direito da Universidade de São Paulo, 2012.

\footnotetext{
' Bacharel em Ciências Sociais pela Universidade Federal do Rio Grande do Sul. Contato: giovani1789@ hotmail.com .

ii $\mathrm{O}$ espaço favorecido ao cristianismo, em especial à religião católica, é reflexo da construção social e cultural da sociedade brasileira. Durante o período colonial (1500-1822) os colonizadores portugueses identificavam como objetivo a evangelização da população local e, posteriormente, os escravos de origem africana. O regime de padroado auxiliava a prática de formação religiosa e a educação tornou-se campo de atuação da Igreja Católica.

iii A promulgação da $1^{\text {a }}$ Constituição (1891) foi a única a excluir o Ensino Religioso das escolas públicas, iniciando o princípio de ensino leigo para corresponder ao novo ordenamento jurídico de princípio de laicidade. Porém não significou a completa ausência da disciplina. Ranquetat Jr. (2007) acrescenta que o ensino do catecismo já fazia parte da grade escolar nas escolas públicas de Minas Gerais antes da promulgação da Constituição de 1934, em decreto conduzido em 1928.

iv $\mathrm{Na}$ época, ocorreu um concurso público abrindo 500 vagas para professores de Ensino Religioso, separados entre católicos, evangélicos e outros. Segundo Cavaliere (2007), as escolas não conseguiram cumprir a demanda e diversas crenças não foram representadas em sala de aula e, por conseguinte, o modelo não foi bem recebido, de acordo com sua pesquisa em 14 escolas fluminense.

${ }^{v}$ O FONAPER se apresenta como uma associação civil de direito privado, de âmbito nacional, sem vinculo político-partidário, confessional e sindical, sem fins econômicos, que congrega, conforme seu estatuto, pessoas jurídicas e pessoas naturais identificadas com o Ensino Religioso, sem discriminação por qualquer natureza. O grupo foi criado em 1995, em Florianópolis/
} 
SC, com o objetivo de acompanhar, organizar e subsidiar, ao lado de pesquisadores, professores, sistemas de ensino e associações na efetivação do Ensino Religioso como componente curricular. Disponível em http:<//www.fonaper.com.br/>. Acesso em: 27nov. 2018.

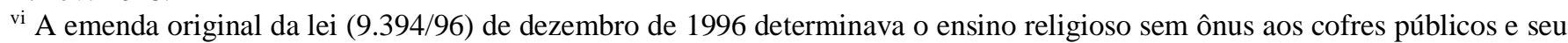
conteúdo podendo ser elaborado de duas maneiras: de caráter confessional ou interconfessional (resultante do acordo entre as diversas entidades religiosas, que se responsabilizarão pela elaboração do respectivo programa). Em julho de 1997 a emenda sofreu modificações excluindo a parte "sem ônus aos cofres públicos" e os modelos definidos como confessional e interconfessional.

vii STF. Supremo Tribunal Federal. Imprensa. Noticias do STF. "STF inicia julgamento que discute ensino religioso nas escolas públicas. 30/08/2017. Disponível em: <http://www.stf.jus.br/portal/cms/verNoticiaDetalhe.asp?idConteudo=354202 >. Acesso: 31 jul. 2019.

viii O Ministro Relator, Luis Roberto Barroso, apontou durante a votação que o Ensino Religioso já é uma exceção à laicidade, mas o modelo confessional seria inconstitucional, pois identifica a relação entre Estado e religião. A Procuradoria Geral defende o modelo não confessional em que a disciplina passa a ter como conteúdo programático a exposição das doutrinas, práticas e dimensões sociais das diferentes religiões, incluindo não religiosas. A ideia é, também, que os professores de Ensino Religioso não estejam presentes em sala de aula como representantes de determinada crença.

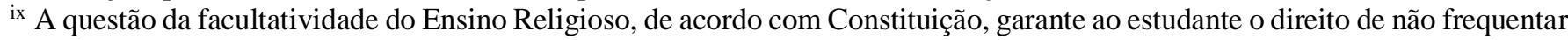
a disciplina. Porém, muitos alunos e pais não são avisados sobre essa questão, conforme será exposto na entrevista com a professora Claudia.

x Jair Messias Bolsonaro foi eleito, após vencer o candidato Fernando Haddad do Partido dos Trabalhadores (PT), presidente do Brasil com 55, 13\% dos votos. Disponível: <https://www1.folha.uol.com.br/poder/eleicoes/2018/apuracao/2turno/brasil/> Acesso em: 31 jul.2019

xi https://noticias.uol.com.br/politica/ultimas-noticias/2019/01/01/bolsonaro-fala-em-combater-ideologia-de-genero-vejaintegra-do-discurso. htm Acesso 14 mar. 2019.

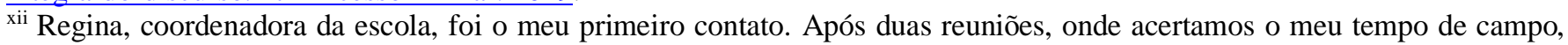
recebi a permissão para frequentar as aulas de Ensino Religioso.

xiii Durante as aulas foram trabalhados temas como feminismo, censura e liberdade de expressão. No material relacionado ao feminismo, ele levou músicas de funk, pop e rock que tinham mulheres como protagonistas. No final da atividade, alguns alunos escreveram músicas com letras de apoio à causa. Sobre ética, censura e liberdade, o professor utilizou como referência os 50 anos do Golpe militar, período que se perpetuou entre 1964 até 1985. Ele expôs aos alunos músicas que foram censuradas durante o período. Entre os artistas perseguidos estavam Chico Buarque com as músicas Apesar de Você e Cálice (em parceria com Milton Nascimento) e Caetano Veloso com Alegria, Alegria durante o governo Médici. As músicas, em forma de metáfora, denotavam críticas à violência do período. Foi aplicado um trabalho, em torno do conteúdo proposto, no qual os alunos deveriam discorrer em um texto sobre liberdade e como ela deveria ser utilizada. Alertou os alunos que a liberdade de expressão não pode ser confundida com preconceito, pois no momento que a uma manifestação ofende uma pessoa ela deixa de ser opinião e passa a ser discurso de ódio.

xiv $\mathrm{O}$ único momento do campo que a religião foi colocada em debate, ocorreu na sala de professores onde fui questionado sobre a minha presença pela professora de Matemática, Júlia. Após relatar o interesse da minha pesquisa, os professores, Júlia, José, Carmen (Educação Física) e Paulo (Geografia), começaram a debater sobre religião. Ambos os professores demonstraram uma posição cética em relação à religião, principalmente aos pastores das igrejas evangélicas. José afirmou que o que incomoda é a posição da hierarquia divina, como se tivesse que seguir regras, ou seja, perdendo a sua liberdade. Carmen apontou não seguir nenhuma religião, mas acreditava na presença de Deus e contou uma história onde ao chegar, eventualmente, mais cedo em casa conseguiu salvar o pai que estava passando por problemas cardíacos. Notei que uma das professoras ficou um pouco desconfortável com o assunto. Raquel (Matemática), evangélica, disse que frequenta a igreja e não vê problema nenhum na religião, não sente que perde a sua liberdade ao seguir os conceitos religiosos. "Sou muito feliz e livre com a minha religião, não me sinto presa em nada" reforçou a professora ao ser questionada sobre sua crença.

xv Disponível em: <https://g1.globo.com/pop-arte/noticia/youtuber-julio-cocielo-e-criticado-por-comentario-sobre-mbappeconseguiria-fazer-uns-arrastao-top-na-praia.ghtml> Acesso: 14 mar. 2019.

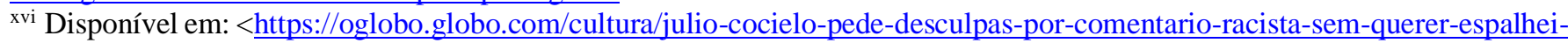
odio-22853670>. Acesso em: 14 mar. 2019.

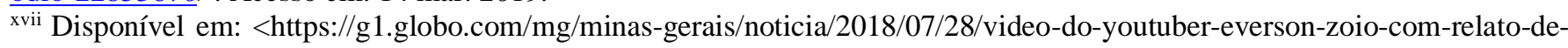
suposto-estupro-e-investigado-por-delegacia-em-belo-horizonte.ghtml>. Acesso em: 16 nov. 2018.

xviii Segundo a professora Claudia, a escola recebe um manual, com detalhes de como conduzir a disciplina, da Secretaria de Educação do Rio Grande do Sul. O material é semelhante ao estudo programado pelo FONAPER. Ou seja: O currículo da disciplina apresenta um ensino voltado para Culturas e Tradições Religiosas (Filosofia e Tradição Religiosa, História Tradição Religiosa, Sociologia e Tradição Religiosa, Psicologia e Tradição Religiosa), Escrituras Sagradas e/ou Tradições Orais (Revelação, História das narrativas sagradas, Contexto Cultural, Exegene) Teologias (Divindades, Verdades de Fé, Vida alémmorte), Ritos (Rituais, Símbolos e Espiritualidades), Ethos (Alteridade, Valores e Limites). O Não Religioso aparece como 
Perspectivas Não Religiosa (Ateísmo, Agnosticismo, Ceticismo e Materialismo) e Visão sem o Transcendente (Projeto existencial de ser humano e morte numa visão sem o transcendente).

xix Disponível em: <https://www.facebook.com/quemmatouocaixeta〉. Acesso em: 27/11/2018. A história também está disponível em versão impressa.

${ }^{x x}$ Entre os insultos, Caixeta falou para um rapaz "Olha aí o gordinho fazendo gordice"; para um casal heterossexual "É isso aí, mano! Mulher casada tem que andar acompanhada"; para duas mulheres "É gostosa mesmo! Se não gosta de elogio, então não se veste assim, pô"; para um casal de lésbicas "Poxa, que desperdício! Se é por falta de macho a solução está bem aqui"; para uma mulher negra: "Parabéns! Tu é negra, mas é linda! Tem uma beleza, tipo exportação"; para um grupo de homossexuais: "Mas é um bando de viado, hein! Nada contra vocês, mas de mãos dadas aqui não dá, né? Tem crianças vendo! Não precisa incentivar, né?

${ }^{\text {xxi }}$ Na primeira escola onde José ministrou as aulas de Ensino Religioso, a professora Terezinha, responsável por ministrar as aulas de Português e Ensino Religioso, afirmou ter receio em aplicar qualquer conteúdo vinculado à cultura afro-brasileira devido a possível recepção negativa dos pais ou responsáveis dos alunos.

xxii Além de atuar na área da educação, o professor é cartunista autônomo que costuma participar de painéis sobre diversidade sexual nos quadrinhos em eventos regionais. É presente nas redes sociais e em manifestações políticas e sociais, principalmente relacionado à comunidade LGBTS. Isso o torna engajado em levar assuntos relacionados às minorias para a sala de aula. 